\title{
PROYEKSI KEBUTUHAN AIR BAKU KOTA TASIKMALAYA PADA TAHUN 2025
}

\author{
(Water Demand Projections of Tasikmalaya in 2025) \\ Nugraha Sadeli Utama ${ }^{1}$ \\ ${ }^{1}$ Program Studi Teknik Sipil Universitas Gunadarma \\ E-mail: nugraha utama@staff.guandarma.ac.id
}

\begin{abstract}
ABSTRAK
Air merupakan kebutuhan dasar yang sangat dibutuhkan oleh mahluk hidup. Air juga menjadi kebutuhan dalam setiap rumah tangga, kegiatan pertanian, ekonomi, dan industri. Permasalahan air setiap hari semakin kompleks. Masalah yang umum dihadapi saat ini adalah konsumsi air yang terus meningkat sejalan dengan pertambahan penduduk, sedangkan sumber air bersih semakin menurun dari segi kualitas dan kuantitas. Untuk memperhitungkan kebutuhan air tersebut maka diperlukan sebuah kajian mengenai proyeksi jumlah penduduk dan proyeksi kebutuhan air baku pada masa yang akan datang. Pada penelitian ini, perhitungan kebutuhan air baku terdiri atas perhitungan kebutuhan air domestik (rumah tangga), kebutuhan air non-domestik (perkotaan) dan kebutuhan air industri. Metode proyeksi yang digunakan adalah Mathematical Logistic Curve Method. Kebutuhan air baku ini kemudian di analisis keterkaitannya dengan ketersediaan air baku. Berdasarkan hasil perhitungan yang telah dilakukan, jumlah penduduk kota Tasikmalaya pada tahun 2025 adalah sebesar 668.281 jiwa, kebutuhan air baku kota Tasikmalaya pada tahun 2025 adalah sebesar 2.100 liter/detik, dan ketersediaan air baku kota Tasikmalaya pada tahun 2025 adalah sebesar 944,18 liter/detik. Ketersediaan kurang dari kebutuhannya, sehingga terjadi defisit air baku sebesar 1.155,82 liter/detik.
\end{abstract}

Kata Kunci: proyeksi penduduk, kebutuhan air baku, ketersediaan air baku

\begin{abstract}
Water is a basic requirement that is needed by living things. Water is also need in every household, agricultural, economic, and industrial. A common problem that we faced today is the consumption of water continues to increase in line with population growth, while diminishing water resources in terms of quality and quantity. To calculate the water needs, a study be required on population projections and projected water requirements in the future. In this study, the calculation of the water demand consist of calculation of domestic water needs (household), calculation of non-domestic water needs (municipal), and calculation of industrial water needs. The projection method used in this study is Mathematical Logistic Curve Method. Based on calculations that have been done, population of Tasikmalaya in 2025 are 668,281 peoples, water demand of Tasikmalaya in 2025 is 2,100 liters/sec, and the water avaibility of Tasikmalaya in 2025 is 944.18 liters/sec. Avaibility less than requirement, so there is a water deficit 1,155.82 liters/sec.
\end{abstract}

Keywords: population projections, water needs, water avaibility. 


\section{PENDAHULUAN}

Air merupakan kebutuhan dasar yang sangat dibutuhkan oleh mahluk hidup. Air juga menjadi kebutuhan dalam setiap rumah tangga, kegiatan pertanian, ekonomi, dan industri. Permasalahan air setiap hari semakin kompleks. Masalah yang umum dihadapi saat ini adalah konsumsi air yang terus meningkat sejalan dengan pertambahan penduduk, sedangkan sumber air bersih semakin menurun dari segi kualitas dan kuantitas.

Millennium Development Goals (MDGs) merupakan paradigma pembangunan global yang mempunyai 8 tujuan dengan 18 sasaran. Sasaran yang berkaitan dengan penyediaan air bersih adalah sasaran kesepuluh, yaitu penurunan sebesar separuh proporsi penduduk yang tidak memiliki akses terhadap sumber air minum yang aman dan berkelanjutan serta fasilitas sanitasi dasar pada Tahun 2015 (UNDP, 2004).

Latar belakang sasaran ini adalah masih banyaknya penduduk dunia yang belum mempunyai akses terhadap air bersih. Pada awal Tahun 2000, diperkirakan 1,1 milyar pendunduk dunia yang tinggal di desa maupun kota hidup tanpa akses air bersih yang aman (WSCC, 2004).

Keberadaan air bersih di daerah perkotaan menjadi sangat penting mengingat aktivitas kehidupan masyarakat kota yang sangat dinamis. Untuk memenuhi kebutuhan air bersih penduduk daerah perkotaan tidak dapat mengandalkan air dari sumber air langsung seperti air permukaan dan hujan karena kedua sumber air sebagian besar telah tercemar baik langsung maupun tidak langsung dari aktivitas manusia itu sendiri. Air tanah merupakan salah satu alternatif untuk memenuhi kebutuhan tersebut, tetapi mempunyai keterbatasan baik secara kualitas maupun kuantitas. Selain itu pengambilan air tanah secara berlebih tanpa mempertimbangkan kesetimbangan air tanah akan memberikan dampak lain seperti penurunan muka tanah, intrusi air laut dan lain-lain.

Seiring dengan bertambahnya jumlah penduduk, kebutuhan akan air baku pun akan semakin meningkat. Kebutuhan air baku dalam hal ini adalah air yang digunakan untuk kebutuhan rumah tangga (domestik). Untuk memperhitungkan kebutuhan air domestik tersebut maka diperlukan sebuah kajian mengenai proyeksi jumlah penduduk pada masa yang akan datang.

Dalam memperhitungkan kebutuhan air baku sebuah kota, diperlukan pula kajian mengenai proyeksi kebutuhan air baku bagi industri dan kebutuhan air baku bagi fasilitas kota itu sendiri. Air yang digunakan harus sesuai dengan jumlah (kuantitas) dan mutu (kualitas) sehingga dapat digunakan dengan baik dan tidak menimbulkan efek samping yang membahayakan pemakai.

Kota Tasikmalaya secara geografis berada di bagian tenggara wilayah Provinsi Jawa Barat dengan jarak dari ibukota provinsi, Bandung, $\pm 105 \mathrm{~km}$ dan dari ibukota negara, Jakarta, $\pm 255 \mathrm{~km}$. Wilayah ini berada pada posisi $108^{\circ} 08^{\prime} 38^{\prime \prime}-108^{\circ} 24^{\prime} 02^{\prime \prime}$ BT dan $7^{\circ} 10^{\prime}-7^{\circ} 26^{\prime}$ 32" LS.

Sebagai kota kecil yang sedang berkembang, selain bertambahnya jumlah penduduk, kegiatan bisnis, perdagangan dan jasa pun ikut berkembang. Hampir $70 \%$, pusat bisnis, pusat perdagangan dan jasa, dan pusat industri di priangan timur dan selatan berada di kota Ini. Priangan Timur dan selatan yakni membentang dari Kota Banjar di ujung timur jawa barat, Kabupaten Ciamis, Kabupaten dan Kota Tasikmalaya, Kabupaten Garut, Kabupaten Sumedang, Kabupaten Cianjur, Kabupaten dan Kota Sukabumi di ujung barat jawa barat, Wilayah priangan timur dan selatan ini mencapai $40 \%$ total keseluruhan wilayah Jawa Barat, itu artinya sepertiga lebih dari pusat perekonomian yang ada di Jawa Barat berada di Kota ini.

Secara umum, permasalahan yang dihadapi kota kecil yang sedang berkembang seperti kota Tasikmalaya dalam hal kebutuhan air baku dapat digambarkan melalui sebuah diagram simple causal loop seperti yang ditunjukan oleh Gambar 1.

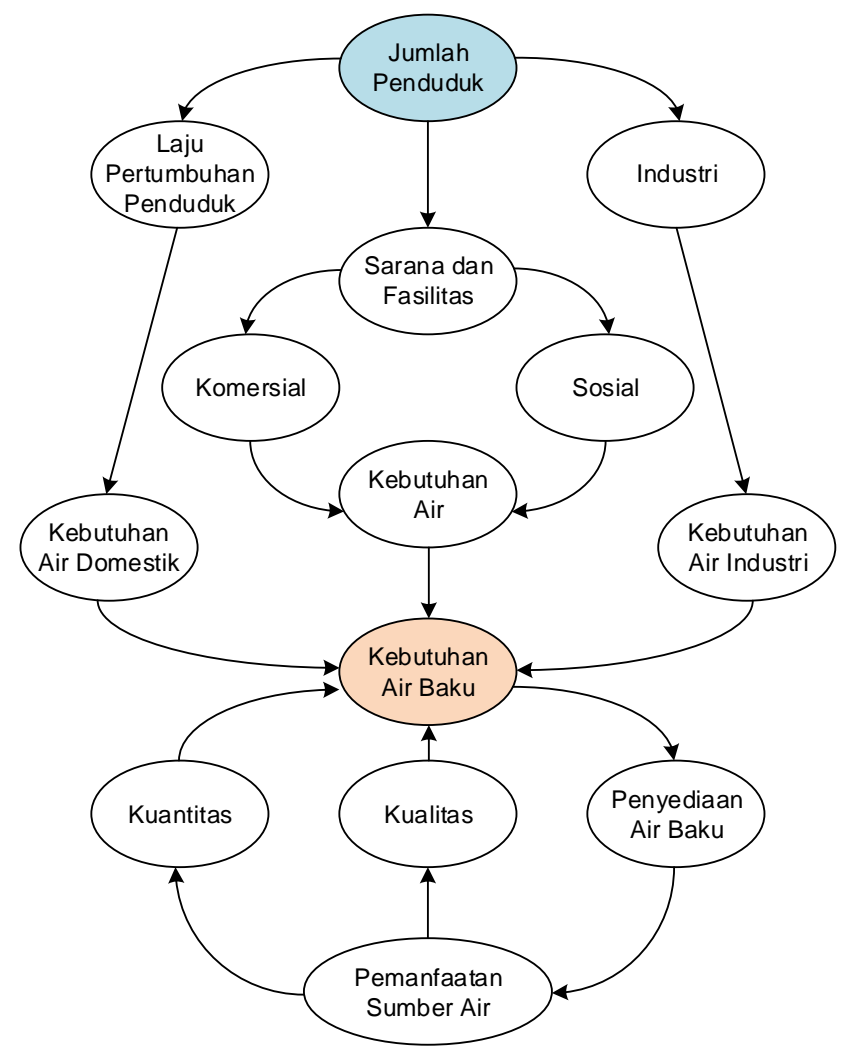

Gambar 1. Simple Causal Loop Kebutuhan Air

Jumlah penduduk kota Tasikmalaya terus mengalami kenaikan dari tahun ke tahun. Jumlah penduduk yang terus meningkat ini menyebabkan kebutuhan air rumah tangga (domestik) pun ikut meningkat. Selain itu, kebutuhan akan fasilitas kota pun ikut meningkat untuk menunjang aktifitas penduduknya. Baik itu fasilitas sosial maupun fasilitas komersialnya. Secara otomatis, kenaikan akan jumlah fasilitas kota akan membuat kebutuhan air terus bertambah. 
Sektor industri pun tak luput dari perkembangan. Kebutuhan dan jumlah penduduk yang terus berkembang memaksa sektor industri untuk ikut berkembang mengikuti kebutuhan penduduk kota. Seiring dengan bertambahnya jumlah industri, maka kebutuhan akan air baku pun akan semakin bertambah.

Untuk memenuhi kebutuhan air baku tersebut maka diperlukan penyediaan air baku dengan memanfaatkan sumber-sumber air yang tersedia. Tentu dengan memperhatikan sisi kuantitas maupun kualitasnya.

\section{METODE}

Pada penelitian ini, perhitungan kebutuhan air baku terdiri atas perhitungan kebutuhan air domestik (rumah tangga), perhitungan kebutuhan air non-domestik (perkotaan), dan kebutuhan air industri. Untuk menentukan proyeksi penduduk pada masa yang akan datang dapat digunakan beberapa metode, antara lain:

1. Arithmetic Growth Method, asumsi pada metode ini adalah tingkat pertumbuhannya konstan.

$$
\begin{aligned}
& P_{t}=P_{0}+K_{a} t \\
& K_{a}=\frac{P_{2}-P_{1}}{\Delta t}\left[T^{-1}\right]
\end{aligned}
$$

dimana,

$P_{t}=$ proyeksi populasi tahun ke- $\mathrm{t}$ setelah $\mathrm{P}_{0}$

$P_{0}=$ populasi pada masa sekarang

$P_{1}=$ populasi awal

$P_{2}=$ populasi akhir

$t=$ periode proyeksi

2. Geometric Growth Method, asumsi pada metode ini adalah tingkat pertumbuhannya relatif meningkat pada masa yang akan datang.

$$
\begin{aligned}
& \ln P_{t}=\ln P_{0}+K_{p} t \\
& K_{p}=\frac{\ln P_{2}-\ln P_{1}}{\Delta t}\left[T^{-1}\right] \\
& P_{t}=\text { proyeksi populasi tahun ke- } \mathrm{t} \text { setelah } \mathrm{P}_{0} \\
& P_{0}=\text { populasi pada masa sekarang } \\
& P_{1}=\text { populasi awal } \\
& P_{2}=\text { populasi akhir } \\
& t=\text { periode proyeksi }
\end{aligned}
$$

3. Decllining Growth Rate Method, asumsi pada metode ini adalah sebuah kota memiliki titik kejenuhan jumlah penduduk sehingga tingkat pertumbuhannya relatif menurun pada masa yang akan datang.

$$
P_{t}=P_{0}+\left(P_{\text {sat }}-P_{0}\right)\left(1-e^{-K_{D} t}\right)
$$

$$
\text { dimana, }
$$

$P t=$ proyeksi tahun ke-t setelah $P_{0}$

$P_{0}=$ populasi saat ini

$P_{\text {sat }} \quad=$ populasi pada titik jenuh

$t=$ periode proyeksi

$$
P_{\text {sat }}=\frac{2 P_{0} P_{1} P_{2}-P_{1}^{2}\left(P_{0}+P_{2}\right)}{P_{0} P_{2}-P_{1}^{2}}
$$

$$
K_{D}=-\frac{1}{\Delta t} \ln \left(\frac{P_{s a t}-P_{2}}{P_{s a t}-P_{1}}\right)\left[T^{-1}\right]
$$

dimana,

$P_{0}=$ populasi pada saat $\mathrm{t} 1$

$P_{1}=$ populasi pada saat $\mathrm{t} 2$

$P_{2}=$ populasi pada saat $\mathrm{t} 3$

4. Mathematical Logistic Curve Method, Logistic Curve Method merupakan kombinasi antara Geometric Growth Method pada saat populasi rendah dan Declining Growth Method pada saat kota mencapai titik jenuh pertumbuhan jumlah penduduknya. Dengan demikian metode ini memiliki bentuk kurva$\mathrm{S}$.

$$
\begin{aligned}
& P_{t}=\frac{P_{s a t}}{1+a e^{b t}} \\
& P_{\text {sat }}=\frac{2 P_{0} P_{1} P_{2}-P_{1}^{2}\left(P_{0}+P_{2}\right)}{P_{0} P_{2}-P_{1}^{2}} \\
& a=\frac{P_{\text {sat }}-P_{0}}{P_{0}} \\
& b=\frac{1}{n} \ln \left[\frac{P_{0}\left(P_{s a t}-P_{1}\right)}{P_{1}\left(P_{s a t}-P_{0}\right)}\right]
\end{aligned}
$$

dimana,

$P_{t} \quad=$ populasi pada tahun ke-t setelah $\mathrm{P}_{0}$

$P_{1}, P_{2}=$ populasi penduduk pada saat interval periode sensus

$P_{\text {sat }} \quad=$ populasi pada titik jenuh

$a, b=$ konstanta

$n \quad=$ interval periode sensus

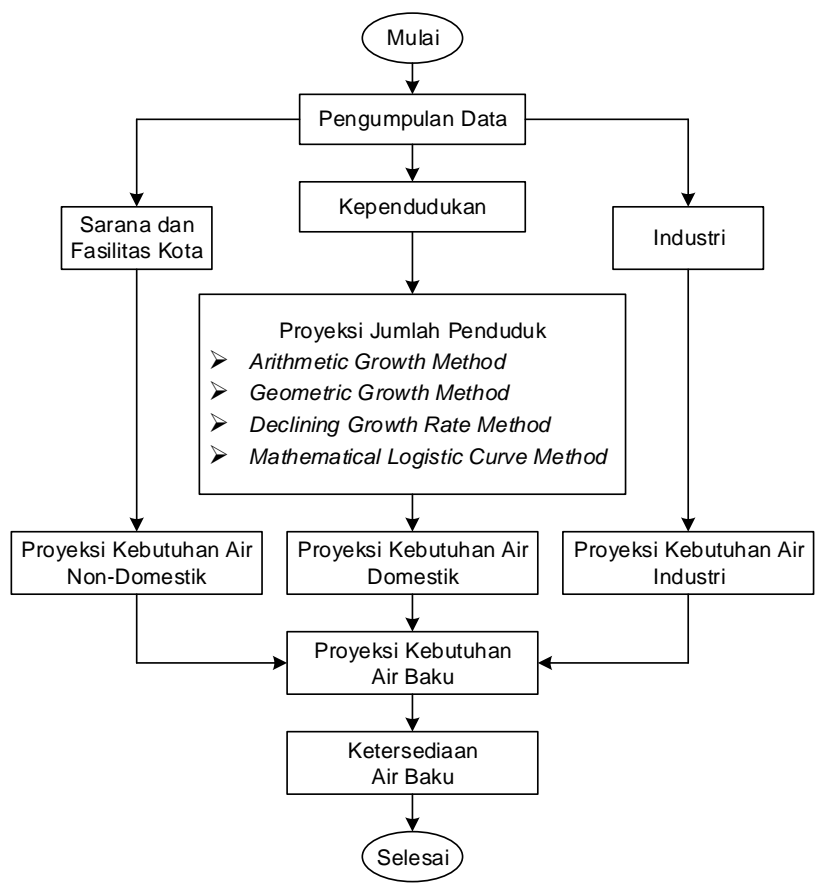

Gambar 2. Proses Penelitian

Berbagai hubungan matematis dipergunakan untuk memproyeksikan jumlah penduduk di masa depan. Koefisien-koefisien nya diperoleh dari data di masa lalu. Dalam menentukan metode proyeksi yang digunakan, 
dilakukan analisis trendline pertumbuhan penduduk dari masa lampau hingga masa sekarang.

\section{HASIL DAN PEMBAHASAN}

Analisis Proyeksi Penduduk

Tabel 1. Jumlah Penduduk Kota Tasikmalaya Tahun 2005-2016

\begin{tabular}{cccc}
\hline Tahun & $\begin{array}{c}\text { Jumlah } \\
\text { Penduduk } \\
\text { (jiwa) }\end{array}$ & $\begin{array}{c}\text { Laju } \\
\text { Pertumbuhan } \\
\text { Penduduk (\%) }\end{array}$ & $\begin{array}{c}\text { Kepadatan } \\
\text { Penduduk } \\
\text { (jiwa/km }{ }^{2} \text { ) }\end{array}$ \\
\hline $\mathbf{2 0 0 5}$ & $\mathbf{5 7 9 , 4 8 2}$ & 0.00 & 3,152 \\
\hline 2006 & 590,870 & 1.97 & 3,214 \\
\hline 2007 & 603,449 & 2.13 & 3,282 \\
\hline 2008 & 615,011 & 1.92 & 3,345 \\
\hline 2009 & 625,210 & 1.66 & 3,401 \\
\hline $\mathbf{2 0 1 0}$ & $\mathbf{6 3 5 , 4 6 4}$ & 1.64 & 3,456 \\
\hline 2012 & 649,885 & 2.27 & 3,535 \\
\hline 2013 & 657,217 & 1.13 & 3,575 \\
\hline 2014 & 654,794 & -0.37 & 3,562 \\
\hline $\mathbf{2 0 1 5}$ & $\mathbf{6 5 7 , 4 7 7}$ & 0.41 & 3,576 \\
\hline 2016 & 659,606 & 0.32 & 3,588 \\
\hline
\end{tabular}

Sumber: BPS Kota Tasikmalaya (diolah)

\section{Pertumbuhan Penduduk Kota Tasikmalaya} Tahun 2005 - 2016

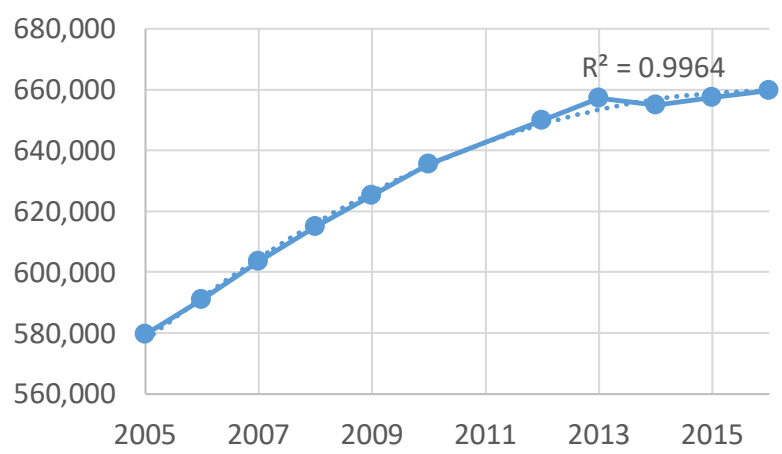

Gambar 3. Grafik Pertumbuhan Penduduk Kota Tasikmalaya Tahun 2005 - 2016

Berdasarkan Tabel 1 dan Gambar 3 di atas, dapat dilihat bahwa trendline grafik pertumbuhan penduduk kota Tasikmalaya cenderung berbentuk kurva-S. Sehingga metode analisis yang digunakan untuk memprediksi jumlah penduduk pada tahun 2025 adalah Mathematical Logistic Curve Method. Logistic Curve Method merupakan kombinasi antara Geometric Growth Method pada saat populasi rendah dan Declining Growth Method pada saat kota mencapai titik jenuh pertumbuhan jumlah penduduknya.

Jumlah penduduk kota Tasikmalaya pada tahun 2005 adalah 579.482 jiwa, pada tahun 2010 sebesar 635.464 jiwa, dan pada tahun 2015 adalah sebesar 657.477 jiwa. Maka dapat diketahui:

$P_{0}=579.482$ jiwa

$P_{1}=635.464$ jiwa

$P_{2}=657.477$ jiwa

$n=5$

Maka,

$$
\begin{aligned}
P_{\text {sat }} & =\frac{2 P_{0} P_{1} P_{2}-P_{1}^{2}\left(P_{0}+P_{2}\right)}{P_{0} P_{2}-P_{1}^{2}} \\
& =\frac{2 \cdot 579482 \cdot 635464 \cdot 657477-635464^{2}(579482+65}{579482 \cdot 657477-635464^{2}} \\
& =669783
\end{aligned}
$$

Saturated Population sebesar 669.783 jiwa,

$$
\begin{aligned}
a & =\frac{P_{\text {sat }}-P_{0}}{P_{0}} \\
& =\frac{669783-579482}{579482} \\
& =0.16
\end{aligned}
$$

Konstanta a bernilai 0.16 ,

$$
\begin{aligned}
b & =\frac{1}{n} \ln \left[\frac{P_{0}\left(P_{\text {sat }}-P_{1}\right)}{P_{1}\left(P_{\text {sat }}-P_{0}\right)}\right] \\
& =\frac{1}{5} \ln \left[\frac{579482(669783-635464)}{635464(669783-579482)}\right] \\
& =-0.21
\end{aligned}
$$

Konstanta b bernilai -0.21 , Maka:

$$
\begin{aligned}
P_{t} & =\frac{P_{s a t}}{1+a e^{b t}} \\
P_{20} & =\frac{669783}{1+0.16 \cdot e^{-0.21 \cdot 20}} \\
& =668281
\end{aligned}
$$

Berdasarkan perhitungan diatas, jumlah penduduk kota Tasikmalaya pada tahun 2025 adalah sebesar 668.281 jiwa. 


\section{Proyeksi Kebutuhan Air Domestik (Rumah Tangga)}

Tabel 2. Kategori Kota Berdasarkan Jumlah Penduduk

\begin{tabular}{|c|c|c|c|c|c|}
\hline \multirow{3}{*}{ URAIAN } & \multicolumn{5}{|c|}{ Kategori Kota Berdasarkan Jumlah Penduduk (Jiwa) } \\
\hline & $>1.000 .000$ & $\begin{array}{c}500.000 \mathrm{~s} / \mathrm{d} \\
1.000 .000\end{array}$ & $\begin{array}{c}100.000 \mathrm{~s} / \mathrm{d} \\
500.000\end{array}$ & $\begin{array}{c}20.000 \mathrm{~s} / \mathrm{d} \\
100.000\end{array}$ & $<20.000$ \\
\hline & $\begin{array}{c}\text { Kota } \\
\text { Metropolitan }\end{array}$ & Kota Besar & $\begin{array}{c}\text { Kota } \\
\text { Sedang }\end{array}$ & Kota Kecil & Desa \\
\hline 1 & 2 & 3 & 4 & 5 & 6 \\
\hline 1. Konsumsi Unit Sambungan Rumah (SR) (liter/org/hari) & $>150$ & $120-150$ & $90-120$ & $80-120$ & $60-80$ \\
\hline 2. Konsumsi Unit Hidran (HU) (liter/org/hari) & $20-40$ & $20-40$ & $20-40$ & $20-40$ & $20-40$ \\
\hline \multicolumn{6}{|l|}{ 3. Konsumsi unit non-domestik } \\
\hline a. Niaga kecil (liter/unit/hari) & $600-900$ & $600-900$ & & & \\
\hline b. Niaga besar (liter/unit/hari) & $1000-5000$ & $1000-5000$ & & & \\
\hline c. Industri besar (liter/detik/ha) & $0.2-0.8$ & $0.2-0.8$ & & & \\
\hline d. Pariwisata (liter/detik/ha) & $0.1-0.3$ & $0.1-0.3$ & & & \\
\hline 4. Kehilangan Air (\%) & $20-30$ & $20-30$ & $20-30$ & $20-30$ & $20-30$ \\
\hline 5. Faktor hari maksimum & $\begin{array}{l}1.15-1.25 \\
\text { *harian }\end{array}$ & $\begin{array}{c}1.15-1.25 \\
\text { *harian }\end{array}$ & $\begin{array}{c}1.15-1.25 \\
\text { *harian }\end{array}$ & $\begin{array}{c}1.15-1.25 \\
\text { *harian }\end{array}$ & $\begin{array}{c}1.15- \\
1.25 \\
\text { *harian }\end{array}$ \\
\hline 6. Faktor jam puncak & $\begin{array}{l}1.75-2.0 \\
\text { *hari maks }\end{array}$ & $\begin{array}{l}1.75-2.0 \\
\text { *hari maks }\end{array}$ & $\begin{array}{l}1.75-2.0 \\
\text { *hari maks }\end{array}$ & $\begin{array}{l}1.75-2.0 \\
\text { *hari maks }\end{array}$ & $\begin{array}{c}1.75-2.0 \\
\text { *hari } \\
\text { maks }\end{array}$ \\
\hline 7. Jumlah jiwa per SR (jiwa) & 5 & 5 & 5 & 5 & 5 \\
\hline 8. Jumlah jiwa per HU (jiwa) & 100 & 100 & 100 & 100 & 100 \\
\hline 9. Sisa tekan di penyediaan distribusi (meter) & 10 & 10 & 10 & 10 & 10 \\
\hline 10. Jam operasi (jam) & 24 & 24 & 24 & 24 & 24 \\
\hline 11. Volume reservoir (\% Max Day Demand) & $15-25$ & $15-25$ & $15-25$ & $15-25$ & $15-25$ \\
\hline 12. SR : HU & $\begin{array}{c}50: 50 \mathrm{~s} / \mathrm{d} \\
80: 20\end{array}$ & $\begin{array}{c}50: 50 \mathrm{~s} / \mathrm{d} \\
80: 20\end{array}$ & $80: 20$ & $70: 30$ & $70: 30$ \\
\hline 13. Cakupan pelayanan (\%) & 90 & 90 & 90 & 90 & 90 \\
\hline
\end{tabular}

Sumber: Kriteria Perencanaan Dirjen Cipta Karya Dinas PU, 1996.

Proyeksi jumlah penduduk kota Tasikmalaya pada tahun 2025 adalah 668.281 jiwa. Dengan jumlah penduduk sebanyak itu, kota Tasikmalaya sudah dapat dikategorikan sebagai kota besar. Mengacu pada tabel 2 , kebutuhan air domestiknya dapat dilihat pada tabel di bawah ini.

Tabel 3. Kebutuhan Air Domestik Kota Tasikmalaya

\begin{tabular}{cccc}
\hline \multirow{2}{*}{ Tahun } & $\begin{array}{c}\text { Jumlah Penduduk } \\
\text { (jiwa) }\end{array}$ & \multicolumn{2}{c}{ Kebutuhan Air } \\
\cline { 3 - 4 } & liter/org/hari & liter/detik \\
\hline $\mathbf{2 0 0 5}$ & $\mathbf{5 7 9 , 4 8 2}$ & 135 & 905.44 \\
\hline 2006 & 590,870 & 135 & 923.23 \\
\hline 2007 & 603,449 & 135 & 942.89 \\
\hline 2008 & 615,011 & 135 & 960.95 \\
\hline 2009 & 625,210 & 135 & 976.89 \\
\hline $\mathbf{2 0 1 0}$ & $\mathbf{6 3 5 , 4 6 4}$ & 135 & 992.91 \\
\hline 2012 & 649,885 & 135 & $1,015.45$ \\
\hline 2013 & 657,217 & 135 & $1,026.90$ \\
\hline 2014 & 654,794 & 135 & $1,023.12$ \\
\hline $\mathbf{2 0 1 5}$ & $\mathbf{6 5 7 , 4 7 7}$ & 135 & $1,027.31$ \\
\hline 2016 & 659,606 & 135 & $1,030.63$ \\
\hline $\mathbf{2 0 2 5}$ & $\mathbf{6 6 8 , 2 8 1}$ & 135 & $\mathbf{1 , 0 4 4 . 1 9}$ \\
\hline $\mathbf{2 u n}$
\end{tabular}

Sumber: BPS Kota Tasikmalaya (diolah)

\section{Proyeksi Kebutuhan Air Non-Domestik (Perkotaan)}

Dalam menentukan kebutuhan air non-domestik (perkotaan), kita dapat mengacu pada tabel 4 dan tabel 5.

Tabel 4. Kebutuhan Air Non-domestik (Perkotaan)

\begin{tabular}{lcl}
\hline \multicolumn{1}{c}{ Sektor } & Nilai & \multicolumn{1}{c}{ Satuan } \\
\hline Sekolah & 10 & liter/siswa/hari \\
\hline Rumah Sakit & 200 & liter/bed/hari \\
\hline Puskesmas & 2000 & liter/unit/hari \\
\hline Mesjid & 3000 & liter/unit/hari \\
\hline Gereja & 1000 & liter/unit/hari \\
\hline Kantor & 10 & liter/pegawai/hari \\
\hline Pasar & 12000 & liter/ha/hari \\
\hline Hotel & 150 & liter/bed/hari \\
\hline Rumah Makan & 100 & $\begin{array}{l}\text { liter/tempat } \\
\text { duduk/hari }\end{array}$ \\
\hline Komplek Militer & 60 & liter/orang/hari \\
\hline $\begin{array}{l}\text { Kawasan Industri } \\
\text { Kawasan } \\
\text { Pariwisata }\end{array}$ & $0.2-0.8$ & liter/detik/ha \\
\hline $\begin{array}{l}\text { Sumber: Kriteria Perencanaan Dirjen } \\
\text { 1996. }\end{array}$ & $0.1-0.3$ & liter/detik/ha Karya Dinas PU, \\
\end{tabular}


Tabel 5. Kebutuhan Air untuk Fasilitas Perkotaan

\begin{tabular}{|c|c|c|c|c|}
\hline Jenis Kebutuhan air & \multicolumn{4}{|c|}{ Jenis Kota } \\
\hline Untuk Fasilitas Perkotaan & Metropolitan & Besar & Sedang & Kecil \\
\hline \multicolumn{5}{|l|}{ Komersial } \\
\hline a. Pasar & $0.1-1,00(\mathrm{l} / \mathrm{d} / \mathrm{ha})$ & & & \\
\hline - Lokal & 400 (I/kamar/hari) & & & \\
\hline - Internasional & $1.000(\mathrm{l} / \mathrm{kamar} /$ hari $)$ & & & \\
\hline c. Hostel & $135-180$ (I/orang/hari) & & & \\
\hline d. Bioskop & 15 (l/orang/hari) & & & \\
\hline \multicolumn{5}{|l|}{ Sosial dan institusia. } \\
\hline a.Universitas & 20 (I/siswa/hari) & & & \\
\hline b.Sekolah & 15 (I/siswa/hari) & $40 \%$ dari & $30 \%$ dari & $25 \%$ dari \\
\hline c.Mesjid & 1 s.d 2 (m3/hari/unit) & $\begin{array}{l}\text { Kebutunan } \\
\text { air baku }\end{array}$ & kebutuhan air & kebutuhan air \\
\hline $\begin{array}{l}\text { a. Ruman sakIt } \\
\text { 1) Kurang dari } 100 \text { tempat tidur }\end{array}$ & 340(l/temnat tidur/hari) & rumah & Daku ruman & Daku ruman \\
\hline 2) Lebih dari 100 tempat tidur & 400-450(I/tempat tidur/hari) & tangga & (domestik) & (domestik) \\
\hline e.Puskesmas & 1 s.d. 2 ( $\mathrm{m}^{3} /$ hari/unit) & (domestik) & & \\
\hline f.Kantor & $0.01-45$ (I/detik/hari) & & & \\
\hline g.Militer & $10\left(\mathrm{~m}^{3} /\right.$ hari/ha $)$ & & & \\
\hline h.Klinik Kesehatan & 135 l/orang/hari & & & \\
\hline \multicolumn{5}{|l|}{ Fasilitas Pendukung Kota } \\
\hline a. Taman Kota & 1,4 liter $/ \mathrm{m}^{2} /$ hari & & & \\
\hline b. Road Watering & $1,0-1,5$ liter $/ \mathrm{m}^{2} /$ hari & & & \\
\hline c. Sewer sistem (air kotor) & 4,5 liter/kapita/hari & & & \\
\hline
\end{tabular}

Tabel 6. Jumlah Sarana Kota Tasikmalaya

\begin{tabular}{|c|c|c|c|c|c|c|c|c|c|c|c|c|c|c|}
\hline \multirow{2}{*}{ No } & \multirow{2}{*}{$\begin{array}{l}\text { Sarana dan } \\
\text { Fasilitas Kota }\end{array}$} & \multicolumn{13}{|c|}{ Jumlah Sarana (Tahun) } \\
\hline & & 2005 & 2006 & 2007 & 2008 & 2009 & 2010 & 2011 & 2012 & 2013 & 2014 & 2015 & 2016 & 2025 \\
\hline 1 & $\begin{array}{l}\text { Sekolah } \\
\text { Siswa) }\end{array}$ & 129,235 & 133,260 & 139,228 & 141,934 & 147,252 & 147,252 & 152,445 & 151,778 & 146,701 & 164,761 & 164,761 & 149,743 & $166,522^{*}$ \\
\hline 2 & $\begin{array}{l}\text { Perguruan Tinggi } \\
\text { (Jumlah } \\
\text { Mahasiswa) }\end{array}$ & 510 & 1,337 & 644 & 1,829 & $\mathrm{n} / \mathrm{a}$ & $\mathrm{n} / \mathrm{a}$ & $\mathrm{n} / \mathrm{a}$ & $\mathrm{n} / \mathrm{a}$ & $\mathrm{n} / \mathrm{a}$ & $\mathrm{n} / \mathrm{a}$ & $\mathrm{n} / \mathrm{a}$ & 7,421 & $13,075^{\star}$ \\
\hline 3 & $\begin{array}{l}\text { Rumah Sakit } \\
\text { (Tempat Tidur) }\end{array}$ & 429 & 429 & 443 & 600 & 600 & $\mathrm{n} / \mathrm{a}$ & $\mathrm{n} / \mathrm{a}$ & $\mathrm{n} / \mathrm{a}$ & $\mathrm{n} / \mathrm{a}$ & $\mathrm{n} / \mathrm{a}$ & $\mathrm{n} / \mathrm{a}$ & 600 & $740^{*}$ \\
\hline 4 & $\begin{array}{lr}\text { Rumah } & \text { Sakit } \\
\text { Bersalin } & \text { (Tempat } \\
\text { Tidur) } & \end{array}$ & 45 & 45 & 82 & 162 & 162 & $\mathrm{n} / \mathrm{a}$ & $\mathrm{n} / \mathrm{a}$ & $\mathrm{n} / \mathrm{a}$ & $\mathrm{n} / \mathrm{a}$ & $\mathrm{n} / \mathrm{a}$ & $\mathrm{n} / \mathrm{a}$ & 162 & $258^{*}$ \\
\hline 5 & $\begin{array}{l}\text { Rumah Bersalin } \\
\text { (Tempat Tidur) }\end{array}$ & 21 & 21 & 21 & 50 & 50 & $n / a$ & $\mathrm{n} / \mathrm{a}$ & $\mathrm{n} / \mathrm{a}$ & $\mathrm{n} / \mathrm{a}$ & $\mathrm{n} / \mathrm{a}$ & $\mathrm{n} / \mathrm{a}$ & 50 & $74^{*}$ \\
\hline 6 & Balai Pengobatan & 50 & 50 & 50 & 30 & 30 & 39 & 39 & 39 & 39 & 57 & 57 & 65 & $77^{*}$ \\
\hline 7 & Puskesmas & 18 & 18 & 18 & 20 & 20 & 40 & 39 & 41 & 41 & 43 & 43 & 21 & $23^{*}$ \\
\hline 8 & Mesjid & 857 & 937 & 837 & 885 & 1,025 & 1,025 & 1,111 & 1,111 & 1,111 & 1,093 & 1,093 & 1,093 & $1,286^{*}$ \\
\hline 9 & Langgar & 1,536 & 1,566 & 1,536 & 1,461 & 1,253 & 1,253 & 1,340 & 1,340 & 1,340 & 1,452 & 1,452 & 1,452 & $1,383^{*}$ \\
\hline 10 & Mushola & 348 & 345 & 730 & 763 & 812 & 812 & 708 & 708 & 708 & 808 & 808 & 808 & $1,184^{*}$ \\
\hline 11 & Gereja & 14 & 14 & 14 & 12 & 14 & 14 & 12 & 12 & 12 & 12 & 12 & 12 & 12 \\
\hline 12 & Kelenteng & 1 & 1 & 2 & 2 & 1 & 1 & 1 & 1 & 1 & 1 & 1 & 1 & 1 \\
\hline 13 & Pura & 0 & 0 & 0 & 0 & 1 & 1 & 1 & 1 & 1 & 1 & 1 & 1 & 1 \\
\hline 14 & $\begin{array}{l}\text { Hotel } \\
\text { Kamar) }\end{array}$ & 889 & 889 & 850 & 957 & 922 & 922 & 962 & 962 & 962 & 962 & 1,107 & 1,107 & $1,285^{\star}$ \\
\hline 15 & $\begin{array}{ll}\text { Pasar } & \text { (Luas } \\
\text { Pasar, ha) } & \end{array}$ & 48 & 48 & 48 & 48 & 48 & 48 & 48 & 48 & 48 & 48 & 48 & 48 & 48 \\
\hline 16 & Bandara (militer) & 70 & 70 & 70 & 70 & 70 & 70 & 70 & 70 & 70 & 70 & 70 & 70 & 70 \\
\hline 17 & Taman Kota (m2) & 100 & 100 & 100 & 100 & 100 & 100 & 100 & 100 & 100 & 100 & 100 & 100 & 100 \\
\hline 18 & $\begin{array}{l}\text { Bioskop (Tempat } \\
\text { Duduk) }\end{array}$ & 72 & 72 & 72 & 216 & 216 & 216 & 216 & 216 & 216 & 216 & 216 & 216 & 216 \\
\hline
\end{tabular}

Ket: * hasil interpolasi

$\mathrm{n} / \mathrm{a}$ tidak tersedia

Sumber : BPS Kota Tasikmalaya (diolah) 
Tabel 7. Kebutuhan Air Non-Domestik Kota Tasikmalaya Tahun 2025

\begin{tabular}{|c|c|c|c|c|c|c|}
\hline \multirow{2}{*}{ No } & \multirow{2}{*}{ Sarana dan Fasilitas Kota } & \multirow{2}{*}{$\begin{array}{c}\text { Tahun } \\
2025\end{array}$} & \multicolumn{4}{|c|}{ Kebutuhan Air } \\
\hline & & & Nilai & Satuan & Tahun 2025 & Satuan \\
\hline 1 & Sekolah (Jumlah Siswa) & 166,522 & 15.0 & liter/siswa/hari & 28.9 & liter/detik \\
\hline 2 & Perguruan Tinggi (Jumlah Mahasiswa) & 13,075 & 20.0 & liter/siswa/hari & 3.0 & liter/detik \\
\hline 3 & Rumah Sakit (Tempat Tidur) & 740 & 400.0 & liter/tempat tidur/hari & 3.4 & liter/detik \\
\hline 4 & Rumah Sakit Bersalin (Tempat Tidur) & 258 & 400.0 & liter/tempat tidur/hari & 1.2 & liter/detik \\
\hline 5 & Rumah Bersalin (Tempat Tidur) & 74 & 400.0 & liter/tempat tidur/hari & 0.3 & liter/detik \\
\hline 6 & Balai Pengobatan & 77 & $1,000.0$ & liter/unit/hari & 0.9 & liter/detik \\
\hline 7 & Puskesmas & 23 & $1,000.0$ & liter/unit/hari & 0.3 & liter/detik \\
\hline 8 & Mesjid & 1,286 & $1,000.0$ & liter/unit/hari & 14.9 & liter/detik \\
\hline 9 & Langgar & 1,383 & $1,000.0$ & liter/unit/hari & 16.0 & liter/detik \\
\hline 10 & Mushola & 1,184 & $1,000.0$ & liter/unit/hari & 13.7 & liter/detik \\
\hline 11 & Gereja & 12 & $1,000.0$ & liter/unit/hari & 0.1 & liter/detik \\
\hline 12 & Kelenteng & 1 & $1,000.0$ & liter/unit/hari & 0.0 & liter/detik \\
\hline 13 & Pura & 1 & $1,000.0$ & liter/unit/hari & 0.0 & liter/detik \\
\hline 14 & Hotel (Jumlah Kamar) & 1,285 & 400.0 & liter/kamar/hari & 5.9 & liter/detik \\
\hline 15 & Pasar (Luas Pasar, ha) & 48 & $12,000.0$ & liter/ha/hari & 6.7 & liter/detik \\
\hline 16 & Bandara (militer) & 70 & $10,000.0$ & liter/ha/hari & 8.1 & liter/detik \\
\hline 17 & Taman Kota (m2) & 100 & 1.4 & liter/m2/hari & 0.0 & liter/detik \\
\hline \multirow[t]{2}{*}{18} & Bioskop (Tempat Duduk) & 216 & 15.0 & liter/orang/hari & 0.0 & liter/detik \\
\hline & & & & JUMLAH & 103.6 & liter/detik \\
\hline
\end{tabular}

Berdasarkan tabel 7 di atas, dapat dilihat bahwa kebutuhan air untuk perkotaan adalah sebesar 103,6 liter/detik. Akan tetapi, nilai tersebut dirasa kurang memadai karena data sarana dan fasilitas kota kurang lengkap. Sehingga untuk menentukan kebutuhan air perkotaan diambil sebesar $40 \%$ dari kebutuhan air domestik (tabel 5 jenis kota besar). Maka, 40\% dari 1.044,19 liter/detik adalah 417, 68 liter/detik.

\section{Proyeksi Kebutuhan Air Industri}

Standar (acuan) untuk menentukan kebutuhan air sesuai dengan jenis industrinya masing-masing belum tersedia hingga saat ini. Oleh karena itu, dalam menentukan kebutuhan air industri digunakan nilai seperti yang tertera pada tabel di bawah ini.

Tabel 8. Kebutuhan Air Industri

\begin{tabular}{|c|c|c|}
\hline No & Parameter & Nilai \\
\hline \multirow[t]{4}{*}{1} & $\begin{array}{l}\text { Kebutuhan Non- } \\
\text { Domestik } \\
\text { Industri (liter/detik/ha) }\end{array}$ & \\
\hline & a. Berat & $0.50-1.00$ \\
\hline & b. Sedang & $0.25-0.50$ \\
\hline & c. Ringan & $0.15-0.25$ \\
\hline 2 & $\begin{array}{l}\text { Kebutuhan hari rata- } \\
\text { rata }\end{array}$ & $\begin{array}{l}\text { Kebutuhan Domestik + Non } \\
\text { Domestik }\end{array}$ \\
\hline 3 & $\begin{array}{l}\text { Kebutuhan hari } \\
\text { maksimum }\end{array}$ & Kebutuhan rata-rata $\times 1.15-1.20$ \\
\hline \multirow[t]{3}{*}{4} & Kehilangan Air & \\
\hline & a. Sistem baru & $20 \% \times$ Kebutuhan rata-rata \\
\hline & b. Sistem lama & $\begin{array}{l}30 \% \text { s } / \mathrm{d} 40 \% \text { kebutuhan rata- } \\
\text { rata }\end{array}$ \\
\hline 5 & Kebutuhan jam puncak & $\begin{array}{l}\text { Kebutuhan rata-rata } \times \text { faktor jam } \\
\text { puncak }(165 \% \mathrm{~s} / \mathrm{d} 200 \%)\end{array}$ \\
\hline
\end{tabular}

air baku, 2000
Berdasarkan Rencana Pola Pemanfaatan Ruang RTRW Kota Tasikmalaya tahun 2014 , perkiraan luas rencana kawasan industri adalah 76,13 ha atau sekitar $0,44 \%$ dari luas kota. Maka kebutuhan air kota Tasikmalaya untuk industri adalah sebagai berikut:

$\mathrm{KA}_{\text {industri }}=76,13$ ha $\times$ 0,5 liter/detik/ha $=38,07$ liter $/$ detik

\section{Proyeksi Kebutuhan Air Baku Kota Tasikmalaya}

Kebutuhan air baku kota Tasikmalaya dapat dirumuskan sebagai berikut:

Kebutuhan hari rata-rata $=$ Kebutuhan Domestik

$$
\begin{aligned}
& + \text { Kebutuhan Perkotaan } \\
& + \text { Kebutuhan Industri } \\
= & 1.044,19 \text { liter/detik } \\
& +417,68 \text { liter/detik } \\
& +38,07 \text { liter/detik } \\
= & 1.499,94 \\
\approx & 1.500 \text { liter/detik }
\end{aligned}
$$

Kebutuhan hari maks. $=$ Kebutuhan hr. rata-rata $\times 1,20$

$$
\begin{aligned}
& =1.500 \times 1,20 \\
& =1.800 \text { liter/detik }
\end{aligned}
$$

$$
\begin{aligned}
\text { Kehilangan Air } & =20 \% \times \text { Kebutuhan rata-rata } \\
& =20 \% \times 1.500 \text { liter/detik } \\
& =300 \text { liter } / \text { detik }
\end{aligned}
$$


Jadi proyeksi kebutuhan air baku kota Tasikmalaya pada tahun 2025 adalah sebesar 1.800 liter/detik + 300 liter/detik $=2.100$ liter/detik.

\section{Ketersediaan Air Baku}

Sistem penyediaan air bersih Kota Tasikmalaya sampai saat ini masih dilayani oleh PDAM Kabupaten Tasikmalaya. Kondisi ketersediaan air baku nya adalah sebagai berikut,

a. Mata air Cipondok, kapasitas debit mata air ini adalah sebesar 355 liter/detik.

b. Mata air Cibunigeulis, kapasitas debit mata air ini adalah sebesar 18 liter/detik.

Rencana pengembangan pelayanan air bersih kota Tasikmalaya untuk jangka menengah dan jangka panjang adalah sebagai berikut, (BAPEDA Kota Tasikmalaya).

Tabel 9. Alternatif Sumber Air

\begin{tabular}{cll}
$\begin{array}{c}\text { No } \\
\text { Zona }\end{array}$ & $\begin{array}{c}\text { Nama Zona dengan } \\
\text { Alternatif Sumber } \\
\text { Air }\end{array}$ & $\begin{array}{c}\text { Kecamatan Yang } \\
\text { Dilayani }\end{array}$ \\
\hline I & $\begin{array}{l}\text { Cipondok } \\
\text { Citanduy }\end{array}$ & $\begin{array}{l}\text { Kecamatan Cihideung } \\
\text { Kecamatan Cipedes } \\
\text { Kecamatan Indihiang }\end{array}$ \\
\hline II & Citanduy & $\begin{array}{l}\text { Kecamatan Cibeureum } \\
\text { Kecamatan Tawang } \\
\text { Kecamatan Tamansari }\end{array}$ \\
\hline III & Ciwulan & Kecamatan Mangkubumi \\
& & Kecamatan Kawalu \\
\hline
\end{tabular}

Sumber: BAPEDA Kota Tasikmalaya

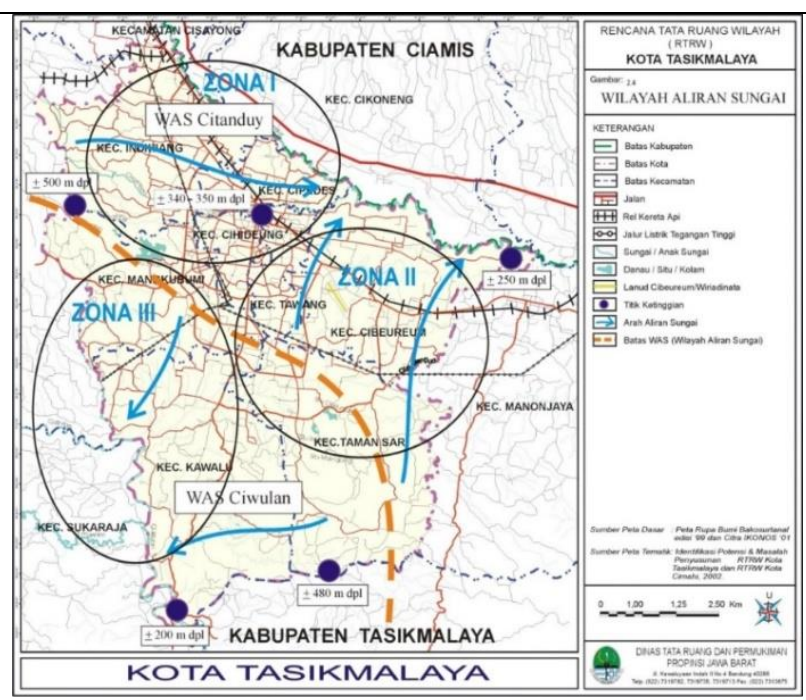

Gambar 4. Wilayah Aliran Sungai

a. Alternatif A (Sistem Penyediaan Air Bersih dengan Mata Air Cipondok)

Mata Air Cipondok direncanakan digunakan sebagai sumber air, dengan daerah pelayanan Zona - 1 yang meliputi Kecamatan Cihideung, Kecamatan Cipedes dan Kecamatan Indihiang. Kapasitas produksi rencana dibagi menjadi dua tahap yaitu, Tahap I (2006 - 2013) sebesar 119,36 liter/detik dan Tahap II (2013 - 2024) sebesar 237,85 liter/detik.

b. Alternatif B (Sistem Penyediaan Air Bersih dengan Sumber Air Baku Sungai Citanduy)

Sungai Citanduy digunakan sebagai sumber air dengan daerah pelayanan utama Zona - 2 yang meliputi Kecamatan Cibeureum, Kecamatan Tawang dan Kecamatan Tamansari. Kapasitas produksi rencana dibagi menjadi dua tahap yaitu, Tahap I (2006 - 2013) sebesar 107,11 liter/detik dan Tahap II (2013 - 2024) sebesar 216,91 liter/detik.

c. Alternatif C (Sistem Penyediaan Air Bersih dengan Sumber Air Baku Sungai Ciwulan)

Sungai Ciwulan digunakan sebagai sumber air baku untuk daerah pelayanan utama Zona - 3 yang meliputi Kecamatan mangkubumi dan Kecamatan Kawalu. Kapasitas produksi rencana dibagi menjadi dua tahap yaitu, Tahap I (2006 - 2013) sebesar 51,14 liter/detik dan Tahap II (2013 - 2024) sebesar 116,42 liter/detik. 
Tabel 10. Ketersediaan dan Kebutuhan Air

\begin{tabular}{|c|c|c|c|c|c|}
\hline Zona & Kecamatan & Sumber Air & $\begin{array}{c}\text { Ketersediaan } \\
\text { Air (liter/detik) }\end{array}$ & $\begin{array}{c}\text { Kebutuhan Air } \\
\text { (liter/detik) }\end{array}$ & Keterangan \\
\hline I & $\begin{array}{l}\text { Cihideung } \\
\text { Cipedes } \\
\text { Indihiang }\end{array}$ & $\begin{array}{ll}\text { Mata Air } & \text { Air } \\
\text { Cipondok Mata } \\
\text { Air Cibunigeulis }\end{array}$ & 610.85 & \multirow{3}{*}{$2,100.00$} & \multirow{4}{*}{$\begin{array}{l}\text { Ketersediaan } \\
\text { kurang dari } \\
\text { kebutuhan, defisit } \\
\text { sebesar 1,155.82 } \\
\text { liter/detik }\end{array}$} \\
\hline II & $\begin{array}{l}\text { Cibeureum } \\
\text { Tawang } \\
\text { Tamansari }\end{array}$ & Sungai Citanduy & 216.91 & & \\
\hline III & $\begin{array}{l}\text { Mangkubumi } \\
\text { Kawalu }\end{array}$ & Sungai Ciwulan & 116.42 & & \\
\hline & & Jumlah & 944.18 & $2,100.00$ & \\
\hline
\end{tabular}

Dapat dilihat pada Tabel 10 diatas, ketersediaan air masih kurang dari kebutuhan air. Terjadi defisit sebesar $1.155,82$ liter/detik. Untuk menutupi defisit tersebut maka kapasitas produksi air baku harus ditingkatkan.

\section{KESIMPULAN}

Berdasarkan hasil penelitian yang telah dibahas sebelumnya, maka dapat ditarik kesimpulan sebagai berikut,

1. Jumlah penduduk kota Tasikmalaya pada tahun 2025 adalah sebesar 668.281 jiwa.

2. Kebutuhan air baku kota Tasikmalaya pada tahun 2025 adalah sebesar 2.100 liter/detik.

3. Ketersediaan air baku kota Tasikmalaya pada tahun 2025 adalah sebesar 944,18 liter/detik.

4. Ketersediaan kurang dari kebutuhannya, sehingga terjadi defisit air baku sebesar 1.155,82 liter/detik.

Untuk penelitian selanjutnya agar melakukan kajian lebih lanjut untuk mengetahui kelayakan sumber-sumber air (sungai Citanduy, sungai Ciwulan, dan situ-situ) yang ada di kota Tasikmalaya apabila sumber-sumber air tersebut akan digunakan sebagai sumber air baku air bersih, baik itu secara kuantitas maupun kualitasnya. Selain itu, perlu adanya kajian mengenai partisipasi sektor industri dalam penyediaan air baku untuk industri.

\section{UCAPAN TERIMA KASIH}

Penulis mengucapkan terima kasih sebesar-besarnya kepada semua pihak yang telah membantu dalam penyelesaian penulisan ini, staf BPS Kota Tasikmalaya, staf BAPEDA Kota Tasikmalaya, staf PDAM Tirta
Sukapura, dan pihak-pihak lain yang tidak dapat penulis sampaikan satu persatu.

\section{REFERENSI}

Wahyuni, Atik., Junianto. (2017). Analisa Kebutuhan Air Bersih Kota Batam pada Tahun 2025. Tapak Vol. 6 No. 2, 2089-2098.

Gaib, Dwi Tirta Yudha., Tanudjaja, Lambertus., Hendratta, Liany A. (2016). Perencanaan Peningkatan Kapasitas Produksi Air Bersih lbukota Kecamatan Nuangan. Jurnal Sipil Statik Vol. 4 No. 8, 2337-6732.

Afrianto, Lukman., Rohmat, Dede., Jupri. (2015). Proyeksi Kebutuhan Air Bersih Penduduk Kecamatan Indramayu Kabupaten Indramayu Sampai Tahun 2035. Antologi Geografi Vol. 3 No. 3.

Susilo, G. E., Purwadi, O.T., Nurayni. (2014). Studi Kebutuhan Air Domestik Untuk Daerah Pantai (Studi Kasus: Kota Bandar Lampung). Jurnal Rekayasa, Vol. 18 No. 3.

Mays Laryy W., 1996. Water Resources Handbook. New York: McGraw Hill Inc.

Suhono, Andreas., dkk. (2007). Buku Panduan Pengembangan Air Minum: RPIJM (Rencana Program Investasi Jangka Menengah) Bidang PU/Cipta Karya. Direktorat Jenderal Cipta Karya Departemen Pekerjaan Umum.

BPS Kota Tasikmalaya. (2005 - 2017). Kota Tasikmalaya Dalam Angka Tahun 2005. Badan Perencanaan Daerah dan Badan Pusat Statistik Kota Tasikmalaya. 
Halaman ini sengaja dikosongkan 